\title{
FUNGSI PENGAWASAN \\ DALAM MENINGKATKAN KEDISIPLINAN GURU DI MTS HASYIM ASY'ARI BANGSRI SUKODONO
}

\author{
Asenan Erik Ibrahim, Romadhona Intan Pratiwi, Aan Nadjib \\ UIN Sunan Ampel, Surabaya - Indonesia | asenanerik72@gmail.com
}

\begin{abstract}
Abstrak: Latar belakang dilakukannya penelitian ini dikarenakan sebuah fenomena yang terjadi pada MTs. Hasyim Asy'ari yaitu kurang optimalnya kinerja guru yang mengabdi disana. Guru seringkali kurang disiplin dalam melaksanakan tugasnya sebagai seorang pendidik. Walaupun tidak semuanya, namun hal ini tentunya akan sangat merugikan apabila tidak dioptimalkan dengan sebaik-baiknya. Penelitian ini bertujuan untuk mendeskripsikan peran dari salah satu fungsi manajemen yaitu pengawasan yang ada di MTs. Hasyim Asy'ari Bangsri, Sukodono, Sidoarjo. Dengan adanya pengawasan, pihak kepala sekolah berharap akan mencapai keberhasilah khususnya dalam memantau kinerja guru yang berhubungan langsung dengan kualitas dan tingkat keberhasilan kegiatan belajar mengajar pada siswa. Landasan yang dipakai dalam penelitian ini adalah pernyataan menurut Siagian, bahwa pengawasan merupakan salah satu fungsi manajemen yang paling penting dan harus dilakukan oleh seorang pimpinan dalam suatu usaha mencapai tujuan organisasi yang dipimpinnya. Penelitian ini menggunakan metode wawancara dan jenis penelitiannya adalah penelitian kualitatif deskriptif. Fungsi utama evaluasi adalah menelaah suatu objek atau keadaan untuk mendapatkan informasi yang tepat sebagai dasar untuk untuk pengambilan keputusan. Seorang pimpinan sekolah harus jeli mengidentifikasi dan mengklasifikasikan permasalahan yang ada sehingga menjadi suatu skala priorotas pemecahan apalagi berhubungan dengan upaya peningkatan kinerja guru. Masalah-masalah yang muncul dalam upaya peningkatan kinerja guru di sekolah merupakan tantangan yang harus diselesaikan karena hal tersebut akan menjadi pelajaran yang berharga untuk mengambil keputusan di kemudian hari.
\end{abstract}

Keywords: pengawasan, manajemen, kinerja dan kedisiplinan guru 


\section{Pemdahuluan}

Proses pendidikan selalu berkaitan erat dengan upaya pengembangan nilai-nilai kemanusiaan. Karena manusialah makhluk yang mempunyai kelebihan dibanding makhluk lain yang ada dibumi. Secara ekstrim bahwa pendidikan merupakan upaya memanusiakan manusia secara manusiawi untuk mengembangkan nilai-nilai kemanusiaan.1

Berdasarkan Undang-Undang Nomor 20 Tahun 2003 Bab II Pasal 3 tentang Sistem Pendidikan Nasional, dijelaskan bahwa "Pendidikan nasional berfungsi mengembangkan kemampuan dan membentuk watak serta peradaban bangsa yang bermartabat dalam rangka mencerdaskan kehidupan bangsa, bertujuan untuk berkembangnya potensi agar menjadi manusia yang beriman dan bertaqwa kepada Tuhan Yang Maha Esa, berakhlak mulia, sehat, berilmu, cakap, kreatif, mandiri, dan menjadi warga negara yang demokratis serta bertanggung jawab". Dari uraian Undang-Undang tersebut dapat ditarik kesimpulan bahwa pendidikan sebagai usaha sadar dan terencana untuk menciptakan suasana belajar dan proses pembelajaran agar peserta didik secara aktif mengembangkan potensi dirinya untuk memiliki kekuatan spiritual keagamaan, pengendalian diri, kepribadian, kecerdasan, akhlak mulia, serta keterampilan yang diperlukan dirinya, masyarakat, bangsa, dan negara. Pendidikan merupakan sarana yang cukup strategis dalam membentuk sumber daya manusia yang berpotensi, bermoral, cerdas dan terambil sesuai dengan undang-undang yang sudah diuraikan diatas.

Hal ini tentunya menjadi tugas sekaligus tantangan bagi sebuah lembaga pendidikan untuk menghasilkan lulusan (output) yang berkualitas, beriman dan bertaqwa serta memiliki karakter yang kuat sehingga dapat menjadi sumber daya manusia yang berguna bagi masyarakat maupun Negara. Benyak sekali aspek yang dapat menentukan mutu dari suatu lembaga pendidikan yang diantaranya adalah sumber daya manusianya, sumber dana, fasilitas, dukungan dari para stakeholder, serta yang tak kalah penting adalah proses manajerial yang ada didalamnya. 


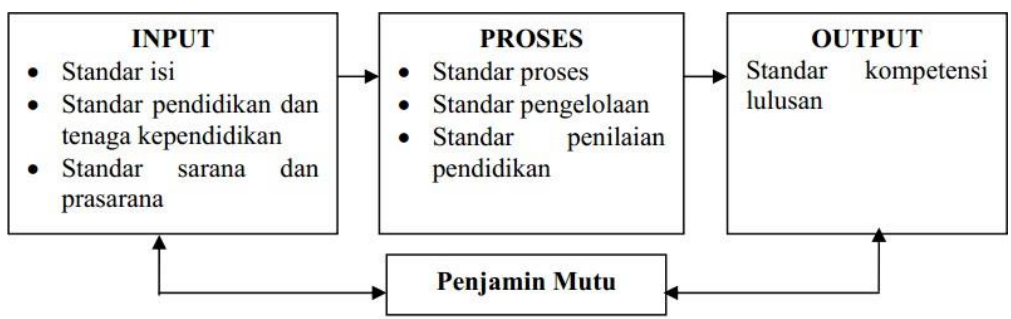

\section{Gambar Alur Pengembangan Mutu Sekolah}

Salah satu pendekatan dalam pengelolaan pendidikan adalah manajemen berbasis sekolah (MBS). Manajemen berbasis sekolah adalah proses mengelola sumber daya secara efektif dan efisien untuk mencapai tujuan yang memberikan otonomi lebih besar kepada sekolah dan mendorong pengambilan keputusan partisipatif secara langsung semua komponen warga sekolah, yaitu: kepala sekolah, guru, siswa, orangtua dan masyarakat. Manajemen berbasis sekolah ini memberikan kebijakan otonomi yang seluasluasnya bagi sekolah dalam mengelola sekolah untuk menentukan keberhasilannya. Keberhasilan sekolah dalam melakukan seluruh aktivitas akademiknya dipengaruhi oleh beberapa hal diantaranya peranan kepala sekolah. Kepala sekolah yang barik adalah dia yang mempunyai seni dalam menjalankan roda manajerial yang ada didalam lembaga yang sedang dipimpinnya.

Kompetensi manajerial merupakan keterampilan kepala sekolah untuk meningkatkan kinerja guru dalam melaksanakan kegiatan belajar mengajar di sekolah. Salah satu fungsi manajerial yang harus dimiliki oleh kepala sekolah adalah pengawasan. Bagaimanapun juga dalam aktivitas pendidikan perlu adanya pengawasan agar aktivitas tersebut dapat berjalan dengan lancar dan teratur, sesuai rencana yang telah ditetapkan sebelumnya sehingga tujuan yang telah ditentukan dapat tercapai.2 Didalam organisasi bahkan lembaga pendidikan, peran kepala sekolah adalah sebagai penggerak atau penentu arah kebijakan lembaga pendidikan tersebut. Kepemimpinan kepala sekolah yang baik harus dapat mengupayakan peningkatan kinerja guru melalui program 
pembinaan kemampuan tenaga kependidikan. Seorang pemimpin harus bisa menjadi teladan yang baik bagi semua elemen yang dibawahinya. Keteladanan pemimpin sangat diperlukan oleh setiap bawahan di organisasi/lembaga manapun. Pemimpin adalah panutan. Ia merupakan tempat bersandar bagi para bawahannya. Pemimpin yang bisa menjadi teladan akan mudah menerapkan disiplin kerja bagi pegawainya.3 Demikian pula sebaliknya, pemimpin yang buruk akan sulit untuk menegakkan kedisiplinan kerja bagi para pegawainya. Oleh karena kepala sekolah harus bisa menjadi contoh bagi para pegawai baik guru maupun staff apabila ingin pegawai tersebut memiliki disiplin kerja sesuai dengan apa yang kepala sekolah inginkan. Seorang pemimpin yang baik juga harus memiliki rasa tanggung jawab yang besar terhadap apa yang ada dalam jangkauan kepemimpinan mereka yang salah satu yang paling penting adalah tentang kinerja guru sehingga kegiatan belajar mengajar yang ada pada lembaga yang dipimpin bisa berjalan dengan lancar dan membawa hasil yang baik bagi siswa karena guru juga merupakan faktor utama dalam proses pendidikan. Guru juga memiliki peranan yang sangat penting dalam menentukan keberhasilan proses belajar mengajar yang ada didalam suatu lembaga pendidikan tersebut.

Guru merupakan salah satu komponen yang sangat menentukan untuk terselenggaranya proses pendidikan, keberadaan guru merupakan pelaku utama sebagai fasilitator penyelenggara proses belajar siswa.4 Seorang guru professional dituntut sejumlah persyaratan, antara lain memiliki kualifikasi pendidikan profesi dan kompetensi keilmuan, memiliki kemampuan berkomunikasi yang baik dengan anak didiknya, mempunyai jiwa kreatif dan produktif, mempunyai etos kerja dan komitmen yang tinggi terhadap profesinya serta selalu melakukan pengembangan diri secara terus-menerus. Oleh karenanya, kinerja guru merupakan hal penting yang harus diusahakan keberhasilannya demi mencapai mutu pembelajaran yang baik karena guru yang berhadapan langsung dengan para peserta didik dalam proses belajar mengajar dikelas. Di tangan guru kepribadian mereka dibentuk. Karena itu, sosok guru yang berkompeten 
sangatlah diperlukan, yang juga memiliki sikap tanggung jawab dan berdedikasi tinggi.

Guru dan kepala sekolah perlu menciptakan sinergitas yang tinggi, menjalin kerjasama, mewujudkan suasana yang kondusif dilandasi oleh semangat kerja ikhlas, kerja keras, kerja cerdas, kerja tuntas, dan kerja berkualitas seuai tupoksinya masing-,masing.5 Dalam tugasnya sebagai seorang manajer, kepala sekolah harus menerapkan prinsip-prinsip kepemimpinan yang kuat dan demokratis karena salah satu kekuatan manajemen terletak pada kepemimpinan seorang manajer yang dalam lingkup ini diperankan oleh seorang kepala sekolah. Kepala sekolah adalah kunci bagi terselenggaranya iklim organisasi sekolah yang kondusif dengan dinamika perubahan yang dilakukan terus-menerus. Manajemen merupakan komponen yang tidak dapat dipisahkan dari proses pendidikan. Untuk itu, kepala sekolah perlu memahami fungsifungsi manajemen yaitu perencanaan, pengorganisasian, pelaksanaan, pengawasan dan pembinaaan, terlebih kepada para guru.

Yayasan Hasyim Asy'ari hadir ditengah-tengah masyarakat desa Bangsri dan sekitarnya untuk bisa memfasilitasi masyarakat untuk mendapatkan sarana pendidikan kepada para anak-anak di daerah tersebut. Yayasan ini sudah dapat memfasilitasi masyarakat karena sudah meemiliki jenjang pendidikan yang lengkap diantaranya pendidikan anak usia dini (PAUD), Taman KanakKanak (TK), Madrasah Ibtidaiyah (MI), Madrasah Tsanawiyah (MTs), Madrasah Aliyah (MA) dan Sekolah Menengah Kejuruan (SMK) yang masing- masing ada dalam satu daerah yang sama yaitu di desa Bangsri.

Dalam penelitian kali ini, penulis tertarik untuk melaksanakan penelitian berdasarkan lokasi Praktik Manajemen Pendidikan Islam (PMPI) yang berada di MTs. Hasyim Asy'ari. Penelitian ini bertujuan untuk mendeskripsikan fungsi pengawasan yang dilakukan oleh kepala sekolah dalam menjalankan roda kepemimpinannya sehingga mampu memecahkan permasalahan yang ada sebelumnya yaitu permasalahan tentan kurang optimalnya kinerja guru. 


\section{Metodologi}

Metode yang digunakan dalam penelitian ini adalah metode kualitatif deskriptif. Peneliti menggunakan pendekatan kualitatif deskriptif dikarenakan data yang dikaji dan dihasilkan adalah deskriptif yaitu berupa kata-kata tertulis atau lisan dari orang-orang dan perilaku yang dapat diamati.6 Metode deskriptif, yaitu metode yang digunakan untuk menganalisis peristiwa-peristiwa pada saat penelitian berlangsung. Menurut Sugiyono "metode penelitian deskriptif adalah metode penelitian yang dilakukan untuk mengetahui nilai variable mandiri atau lebih (independen) tanpa membuat perbandingan atau menggabungkan antara variable satu dengan yang lain".

Penelitian ini dilaksanakan sekitar dua bulan mulai pada tanggal 31 Juli 2019 - 30 September 2019. Penelitian ini memfokuskan dengan menganalisis fenomena yang berhubungan dengan manajemen peningkatan kinerja guru di Madrasah Tsanawiyah Hasyim Asy'ari Bangsri. Berangkat dari fokus penelitian tersebut, maka pendekatan penelitian ini menggunakan pendekatan kualitatif. Nasution merumuskan penelitian kualitatif pada hakikatnya adalah mengamati orang dalam lingkungannya, berinteraksi dengan mereka, berusaha memahami bahasa dan tafsiran mereka tentang dunia sekitarnya7

Menurut Suharsimi Arikunto, subyek penelitian adalah subyek yang dituju untuk diteliti.8 Jika kita bicara tentang subyek penelitian sebetulnya kita berbicara tentang unit analisis, yaitu subjek yang menjadi pusat perhatian atau sasaran. Subyek penelitian disini adalah Kepala dan Guru MTs. Hasyim Asy'ari Bangsri. Data yang diperoleh dari responden melalui teknik observasi, wawancara dan studi dokumentasi merupakan deskripsi tentang pendapat, pengetahuan, pengalaman dan aspek lainnya. Kemudian dianalisis dan disajikan sehingga memiliki arti. 


\section{Hasil dan Pembahasan}

\section{Teori Kepemimpinan Kepala Sekolah}

Kepemimpinan kepala sekolah merupakan suatu kemampuan dan kesiapan kepala sekolah untuk mempengaruhi, membimbing, mengarahkan, dan menggerakkan staf sekolah agar dapat bekerja secara efektif dalam rangka mencapai tujuan pendidikan dan pengajaran yang telah ditetapkan, atau bisa dikatakan bantuan yang diberikan oleh kepala sekolah terhadap penetapan pencapaian tujuan pendidikan.

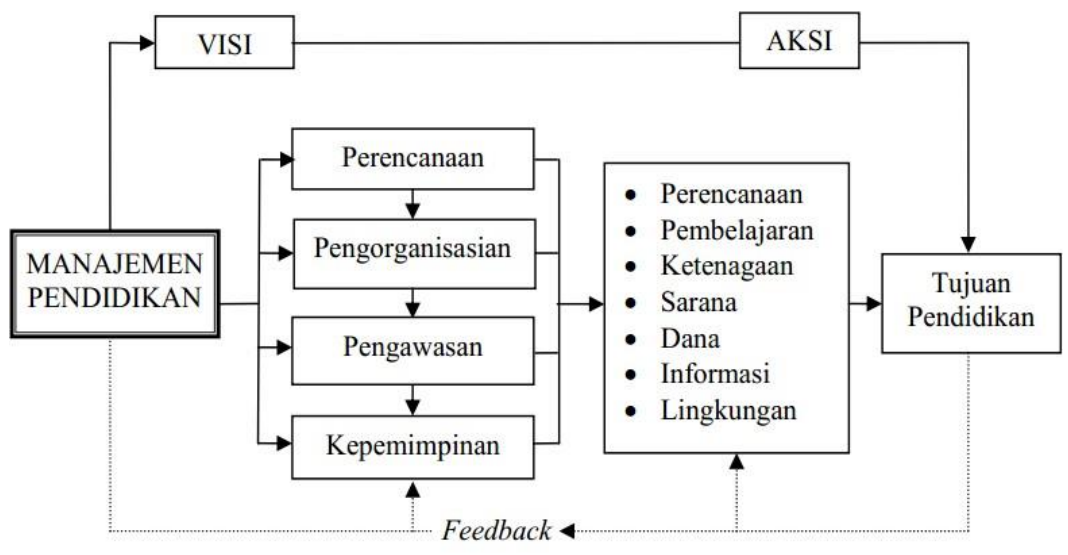

\section{Gambar Bidang Manajemen Pendidikan}

Kepala sekolah yang efektif sedikitnya harus mengetahui, menyadari dan memahami tiga hal: (1) mengapa pendidikan yang berkualitas diperlukan di sekolah; (2) apa yang harus dilakukan untuk meningkatkan mutu dan produktivitas sekolah; dan (3) bagaimana mengelola sekolah secara efektif untuk mencapai prestasi yang tinggi. Indikator-indikator kepemimpinan kepala sekolah yang efektif sebagai berikut:

- Menekankan kepada guru dan seluruh warga sekolah untuk memenuhi norma- norma pembelajaran dengan disiplin yang tinggi. 
- Membimbing dan mengarahkan guru dalam memecahkan masalah-masalah kerjanya, dan bersedia memberikan bantuan secara proporsional dan profesional.

- Memberikan dukungan kepada para guru untuk menegakkan disiplin peserta didik.

- Menunjukkan sikap dan prilaku teladan yang dapat menjadi panutan atau model bagi guru, peserta didik, dan seluruh warga sekolah.

- Membangun kelompok kerja aktif, kreatif, dan produktif.

- Memberikan ruang pemberdayaan sekolah kepada seluruh warga sekolah.

Demikianlah enam indikator kepemimpinan kepala sekolah yang mana apabila terlaksana dengan baik maka organisasi di sekolah dapat mencapai tujuan yang ditetapkan.

\section{Kompetensi Kepala Sekolah}

Berdasarkan Peraturan Menteri Pendidikan Nasional Nomor 13 Tahun 2007 tentang Standar Kepala Sekolah/Madrasah terdisi dari 5 kompetensi, diantaranya:

- Kompetensi Manajerial

- Kompetensi Kewirausahaan

- Kompetensi Supervisi

- Kompetensi Kepribadian

- Kompetensi Sosial

\section{Kinerja Guru}

Dalam Kamus Besar Bahasa Indonesia, kinerja diartikan sebagai sesuatu yang dicapai atau prestasi yang diperlihatkan. Kinerja adalah sebuah kata dari bahasa Indonesia dari kata dasar "kerja" yang menerjemahkan kata dari bahasa asing prestasi. Bisa pula berarti hasil kerja. Setiap individu yang diberi tugas atau kepercayaan untuk bekerja pada suatu organisai tertentu diharapkan mampu menunjukkan kinerja yang memuaskan dan memberikan konstribusi yang maksimal terhadap pencapaian tujuan oraganisasi tersebut.

Undang-Undang Republik Indonesia Nomor 14 Tahun 2005 tentang Guru dan Dosen pasal 35 ayat (1) berbunyi beban kerja guru 
mencakup kegiatan pokok yaitu merencanakan pembelajaran, melaksanakan pembelajaran, membimbing dan melatih peserta didik, serta melaksanakan serta melaksanakan tugas tambahan. Banyak faktor yang dapat mempengaruhi kinerja seorang guru. Maka sebagai pimpinan tertinggi di sekolah, seorang kepala sekolah harus mampu memberikan energi positif yang mampu menggerakkan para guru untuk melaksanakan tugasnya secara sungguh-sungguh dan penuh tanggung jawab sehingga kinerja mereka menjadi lebih baik dan lebih baik lagi. Sebagai pemimpin yang mempunyai pengaruh, seorang kepala sekolah harus terus berusaha agar ide, nasehat, saran, instruksi, perintah dan kebijakannya diikuti oleh para guru yang dibawahinya. Dengan demikian ia dapat mengadakan perubahan-perubahan dalam cara berfikir, dalam bersikap dan dalam bertindak atau berperilaku. Maka menjadi tuntutan bagi seorang kepala sekolah harus selalu me-refresh pengetahuan dan wawasan keilmuannya agar nantinya dapat mendukung tugasnya sebagai seorang pemimpin.

Upaya peningkatan mutu pembelajaran antara lain melalui revitalisasi kinerja kepala sekolah yaitu kegiatan yang harus dilakukan kepala sekolah dan kepemimpinan kepala sekolah yang profesional. Dengan upaya ini diharapkan adanya peningkatan mutu pendidikan nasional. Peningkatan mutu pembelajaran atau mutu sekolah tertuju pada mutu lulusan. Merupakan suatu yang mustahil, pendidikan atau sekolah menghasilkan lulusan yang bermutu, jika tidak melalui proses pembelajaran yang bermutu pula. Dan hal yang mustahil pula, terjadi proses pembelajaran yang bermutu jika tidak didukung oleh faktor- faktor penunjang proses pembelajaran yang bermutu pula. Proses pembelajaran yang bermutu harus didukung oleh personalia, seperti administrator, guru, konselor, dan tata usaha yang bermutu dan profesional.

Kinerja seseorang dapat ditingkatkan apabila ada kesesuaian antara pekerjaan dengan keahliannya, begitu pula halnya dengan penempatan guru pada bidang tugasnya. Menempatkan guru sesuai dengan keahliannya secara mutlak harus dilakukukan. Apabila guru diberikan tugas yang tidak sesuai dengan keahliannya akan berakibat menurunnya cara kerja dan hasil pekerjaan mereka, 
juga akan menimbulkan rasa tidak puas pada diri mereka. Rasa kecewa akan menghambat perkembangan moral kerja guru. Selain dipengaruhi oleh keahlian dan kemampuan dari seorang guru, kinerja dipengaruhi juga oleh kepuasan kerja yaitu perasaan individu terhadap pekerjaan yang memberikan kepuasan batin sehingga pekerjaan tersebut disenangi dan dilaksanakan dengan baik. Untuk mengetahui keberhasilan kinerja perlu dilakukan evaluasi dengan berpedoman pada parameter dan indikator yang telah ditetapkan.

Kinerja guru sangat penting untuk dievaluasi karena guru mengemban tugas professional artinya tugas-tugas hanya dapat dikerjakan dengan kompetensi khusus yang diperoleh melalui program pendidikan. Guru memiliki peranan yang sangat besar bagi terlaksananya kegiatan belajar mengajar yang dapat diklasifikasikan guru sebagai demonstrator, pengelola kelas, mediator dan fasilitator serta evaluator.

\section{Hubungan Pengawasan Kepala Sekolah Dengan Kinerja Guru}

Keberhasilan seorang pemimpin akan terwujud apabila pemimpin tersebut memperlakukan orang lain atau bawahannya dengan baik, serta memberikan motivasi agar mereka menunjukan performance yang tinggi dalam melaksanakan tugas. Menurut Hadari Nawawi, kepemimpinan adalah kemampuan menggerakkan, memberikan motivasi dan mempengaruhi orangorang agar bersedia melakukan tindakan-tindakan yang terarah pada pencapaian tujuan melalui keberanian mengambil keputusan tentang kegiatan yang harus dilakukan.9 Dari uraian diatas dapat disimpulkan bahwa kepemimpinan kepada sekolah sebagai seorang supervisor dalam pengawasan kinerja guru akan berahasil jika kepala sekolah memperhatikan hasil yang dicapai serta memperlakukan guru dengan baik, sehingga mereka mampu menunjukan performace yang lebih baik.

Dari hasil wawancara dan observasi peneliti menemukan adanya perencanaan dalam kegiatan manajemen peningkatan kinerja guru. Perencanaan peningkatan mutu kinerja guru dapat dilaksanakan dengan melakukan analisis SWOT (Strenght, Weakness, Opportunity dan Threath). Perencanaan yang 
dilaksanakan dalam rangka peningkatan kinerja guru di MTs. Hasyim Asy'ari Bangsri dilaksanakan melalui rapat dewan guru. Dalam rapat ini dibahas beberapa agenda antara lain: tujuan peningkatan kinerja guru, jadwal waktu peningkatan kinerja guru, sasaran yang ingin dicapai, sarana dan prasarana pendukung, agenda kegiatan, dan pembiayaan.

Dalam mewujudkan dan melaksanakan semua kegiatan suatu lembaga pendidikan, struktur organisasi merupakan hal yang sangat penting karena setiap lembaga pendidikan merupakan satu kesatuan kerja untuk mencapai suatu tujuan tertentu memerlukan manajemen yang baik maka dari itu agar kegiatan berjalan sesuai dengan tugas pokok dan fungsi sehingga terkoordinir, maka setiap anggota dalam sebuah lembaga pendidikan harus mengetahui tugas, wewenang dan fungsinya masing-masing.

Kepala sekolah memiliki kewajiban meningkatkan kinerja guru, yang pada akhirnya berdampak pada kinerja organisasi sekolah. Gagasan kepala sekolah yang bersifat strategis menjadi hal yang krusial dalam meningkatkan kinerja guru. Berikut ini akan diuraikan kegiatan-kegiatan yang telah diprogram oleh kepala sekolah dalam rangka meningkatkan kinerja guru, yakni:

- Kegiatan belajar mengajar dikelas yang langsung dipantau dan dikontrol oleh wakil kepala sekolah bidang kurikulum yang meliputi pembagian jam mengejar guru (beban kerja), terlambat atau tidak seorang guru datang ke kelas, dan hadir atau tidaknya guru didalam kelas.

- Pertemuan guru yang meliputi kegiatan kekeluargaan yang santai seperti makan- makan dan saling berbincang-bincang setelahnya. Hal ini dilakukan agar terjadi kedekatan emosional antar guru sehingga apabila ada tugas yang belum bisa diselesaikan oleh salah satu guru bisa dibantu dengan guru yang lain. Hal ini juga dilakukan agar tidak terjadi rasa iri terhadap beban kerja yang berbeda masing- masing guru.

- Musyawarah Guru Mata Pelajaran (MGMP). Kegiatan Musyawarah Guru Mata Pelajaran (MGMP) dapat membantu guru dalam membimbing pengalaman belajar siswa, menggunakan media pembelajaran yang berbasis teknologi 
informasi, menilai kemampuan belajar siswa dan dalam pembuatan rencana pemb-elajaran yang akan dilaksanakan. MGMP merupakan salah satu pertemuan yang mewadahi kelompok kerja guru. Kegiatan-kegiatan yang dapat dilaksanakan oleh guru dalam forum MGMP adalah: (1) pendalaman materi; (2) pembuatan perangkat pembelajaran; (3) peningkatan praktik kegiatan belajar mengajar; dan (4) evaluasi pembelajaran. Kegiatan tersebut sangat menunjang kinerja guru di sekolah, terutama dalam bidang pengelolaan kelas.

Adapun setelah terlaksananya tiga kegiatan diatas tersebut, kepala sekolah yang menugaskan wakil kepala sekolah bidang kurikulum disini memberikan penjelasan bahwasannya monitoring dan evaluasi dilaksanakan sesuai dengan program sekolah.

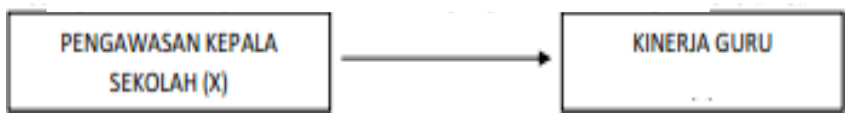

Dalam upaya peningkatan kinerja guru yang dilakukan kepala sekolah tidak lepas dari monitoring dan evaluasi, karena monitoring dan evaluasi merupakan alat kontrol kegiatan dari suatu proses dan tindakan manajemen. Monitoring dan evaluasi dilakukan sebagai acuan dalam pengukuran tingkat keberhasilan sebuah tujuan lembaga yang sudah direncanakan dan dilakukan untuk memenuhi target yang kemudian ditindaklanjuti untuk mengidentifikasikan setiap permasalahan-permasalahan yang muncul.

Fungsi utama evaluasi adalah menelaah suatu objek atau keadaan untuk mendapatkan informasi yang tepat sebagai dasar untuk untuk pengambilan keputusan. Seorang pimpinan sekolah harus jeli mengidentifikasi dan mengklasifikasikan permasalahan yang ada sehingga menjadi suatu skala priorotas pemecahan apalagi berhubungan dengan upaya peningkatan kinerja guru. Masalah-masalah yang muncul dalam upaya peningkatan kinerja guru di sekolah merupakan tantangan yang harus diselesaikan karena hal tersebut akan menjadi pelajaran yang berharga untuk mengambil keputusan di kemudian hari. Kepala sekolah sebaiknya 
memiliki cara atau strategi yang baik dalam menentukan solusi yang tepat dengan melibatkan sumber daya yang ada disekolah dalam rangka mengatasi masalah peningkatan kinerja guru.

Banyak sekali temuan permasalahan yang ada terkait dengan kinerja guru ini, salah satunya adalah banyak sekali guru yang sering tidak hadir dikelas baik itu karena izin maupun alasan yang lain. Hal ini tentunya mendorong kepala sekolah bersama dengan waka kurikulum untuk melakukan evaluasi tersembunyi. Dikatakan evaluasi tersembunyi karena pada awal dilaksanakannya evaluasi ini, kepala sekolah bersama dengan waka kurikulum tidak memberitahu para guru bahwa mereka sedang melakukan evaluasi. Mereka diam-diam melaksanakan evaluasi dengan memantau jurnal belajar harian yang ada di masing-masing kelas sehingga bisa mengetahui siapa saja yang tidak hadir dalam kelas.

Ada hal yang unik ketika proses evaluasi ini berjalan yaitu waka kurikulum dalam melakukan tugasnya langsung memantau kinerja guru melalui jurnal belajar yang ada disetiap kelas. Setelah itu jurnal yang ada tersebut masuk kedalam proses pengolahan sampai pada akhirnya waka kurikulum bisa mengetahui jumlah kehadiran guru dalam tiap bulannya. Tidak berhenti disitu, untuk memberikan efek jera, waka kurikulum juga langsung membagikan hasil olahan data tersebut kedalam grup whatsapp yang beranggotakan para guru yang mengajar di MTs. Hasyim Asy'ari Bangsri.

Hal lain yang dilaksanakan untuk memantau kinerja guru ini yaitu dengan mengadakan alat komunikasi berupa Handie Talkie (HT). HT ini dipegang oleh beberapa guru yang memang diberi kewenangan untuk memantau para guru dilingkungan sekolah. Guru yang memegang HT saling berkoordinasi untuk memantau kelas mana saja yang kosong tanpa kehadiran seorang guru. Setelah hal ini diketahui maka langsung dilakukan laporan kepada pihak kantor untuk mengisi data kelas kosong pada hari yang sama.

Waka Kurikulum menjelaskan pada awal diberlakukannya evaluasi ini, banyak sekali resistensi-resistensi yang bermunculan diantara para guru. Bahkan banyak sekali guru yang berdalih memasuki kelas dengan memberikan tugas walaupun pada 
akhirnya ditinggal mengerjakan kesibukan yang lain. Namun hal ini tetap saja dianggap tidak hadir karena guru tidak menemani proses belajar siswa sesuai dengan jadwal yang sudah ditentukan. Sebelumnya banyak juga guru yang sering sekali melakukan izin tidak bisa hadir dikelas dikarenakan ada urusan lain diluar sekolah. Hal ini tentunya juga sangat berdampak pada kegiatan belajar siswa yang pada akhirnya jadi terbengkalai. Pada akhirnya muncullah ide pengawasan seperti yang disebutkan diatas.

Setelah beberapa bulan diterapkan akhirnya guru di MTs. Hasyim Asy'ari mulai sadar akan peraturan yang ada dan membuat kinerja mereka juga semakin membaik. Hal ini tentu didasarkan pada pengawasan yang rutin dilakukan oleh kepala sekolah bersama dengan waka kurikulum sehingga guru merasa terus diawasi dan tidak pernah lagi melakukan izin-izin atas sesuatu yang kurang penting. Hal ini memberikan dampak yang sangat baik terhadap perkembangan belajar siswa karena mereka mampu terpenuhi haknya secara utuh sebagai siswa di MTs. Hasyim Asy'ari Bangsri. Ini artinya pengawasan yang dilakukan oleh kepala sekolah bersama dengan waka kurikulum berhasil dilakukan untuk meningkatkan kedisiplinan guru di MTs. Hasyim Asy'ari Bangsri.

\section{Kesimpulan}

Kepemimpinan kepala sekolah yaitu proses pemahaman seorang guru dalam memberikan arti mengenai kepemimpinan yang dijalankan oleh kepala sekolah berdasarkan pengamatan, pengalaman, perhatian dan kepercayaan yang terseleksi selama menjadi guru. Dalam tubuh sekolah, kepemimpinan hendaknya dikembangkan diantara semua guru di semua tingkatan. Semua guru hendaknya berpartisipasi dalam mengembangkan visi dan misi sekolah menghadapi era masa depan. Semua anggota kelompok organisasi hendaknya rela menerima tanggung jawab baru, mengambil resiko, membina konsensus, dan saling percaya mempercayai diantara rekan seprofesi. Simpulan penelitian secara umum menunjukkan bahwa fungsi pengawasan yang dilakukan oleh kepala sekolah bersama dengan waka kurikulum untuk meningkatkan kedisiplinan guru di MTs. Hasyim Asy'ari Bangsri 
berjalan sesuai dengan rencana yang telah ditetapkan sekolah dan berhasil membuat guru menjadi semakin disiplin. Kedisiplinan ini berdampak secara langsung terhadap kinerja guru yang ada di MTs. Hasyim Asy'ari Bangsri.

Setelah menyimak hasil atau temuan yang telah dilakukan oleh peneliti, maka peneliti mengajukan beberapa rekomendasi atau saran dalam manajemen peningkatan kinerja guru di MTs. Hasyim Asy'ari Bangsri antara lain:

Kepala sekolah perlu memberikan penguatan kepada guru yang telah berhasil melakukan tugasnya dengan baik, meskipun dengan penguatan yang sederhana seperti pernyataan puas atau pujian. Penguatan diberikan agar guru merasa hasil pekerjaannya dihargai dan diapresiasi, sehingga guru akan merasa senang dan berusaha untuk meningkatkan kinerjanya. Apabila tidak dilakukan, maka akan dikhawatirkan guru akan merasa tidak diapresiasi.

Kepala sekolah beserta kurikulum yang sudah melakukan tugasnya dengan sangat baik supaya terus melakukan kegiatan evaluasi dan pengawasan secara berkelanjutan demi tercapainya iklim pembelajaran yang nyaman bagi siswa di MTs. Hasyim Asy'ari Bangsri.

Kepada guru yang telah berulangkali kurang disiplin sebaiknya mendapatkan sanksi sebab sanksi tersebut tentunya akan membuat efek jera bagi guru sehingga kinerja yang bersangkutan dapat terus meningkat. Apabila tidak ada sanksi terhadap guru maka dimungkinkan kejadian yang serupa akan terulangi kembali.

Kepada guru yang telah berulangkali kurang disiplin agar segera sadar akan tanggungjawab yang benar-benar harus dilaksanakan karena ini menyangkut masa depan seorang siswa yang sedang menuntut ilmu di MTs. Hasyim Asy'ari

\section{References}

Arikunto, Suharsimi. 2006. Metodologi Penelitian. Yogyakarta: Bina Aksara.

Barnawi dan Mohammad Arifin. 2014. Kinerja Guru Profesional. Jogjakarta: Ar-Ruzz Media. 
Kurniawan, Asep. 2011. “Kemampuan Manajerial Kepala Sekolah dalam Meningatkan Kinerja Guru untuk Menciptakan Sekolah yang Bermutu: Penelitian di SDIT Sabilul Huda dan SDIT Sains al-Farabi", Jurnal Holistik, vol. 12, no. 01 (Juni): h. 26.

Moleong, Lexy. 2002. Metodologi Penelitian Kualitatif. Bandung : PT Remaja Rosdakarya.

Nasution. 1998. Metodologi Penelitian Naturalistik Kualitatif. Bandung: Tarsito. Nawawi, Hadari. 1996. Administrasi Pendidikan. Jakarta: Gunung Agung.

Shulhan, Muwahid dan Soim. 2013. Manajemen Pendidikan Islam: Strategi Dasar Menuju Peningkatan Mutu Pendidiakan Islam. Yogyakarta: Penerbit Teras.

Syamsul, Herawati. 2017. "Penerapan Kepemimpinan Kepala Sekolah dalam Meningkatkan Kinerja Guru pada Jenjang Sekolah Menengah Pertama (SMP)" Jurnal Idaarah, vol. 1, no. 2 (Desember): h. 276. 